\title{
Questioning the Direct Impact of International Flower Festival to Increase Welfare of Flower Farmer, A Case in Kakaskasen Village, Tomohon City
}

\author{
Selvy Kalele*, Dianne O. Rondonuwu \\ Tourism Department \\ Politeknik Negeri Manado \\ Manado, Indonesia \\ *selvykalelenew@yahoo.com
}

\begin{abstract}
Tomohon International Flower Festival is an event of flower parade festival which is regularly held in Tomohon City, North Sulawesi Province. The festival aims to promote flowers which are the plants of local communities, as well as various tourist attractions in the city of Tomohon. The festival is expected to provide added value to farmers' interest, regional income and open new market share breakthroughs to be sold to outside region or other countries. This festival has been widely participated in by participants from outside the regions in Indonesia as well as several representatives from other the countries. This festival has become an annual agenda of the Tomohon city government, and of course has significantly affected the local community in the city of Tomohon especially for the flower farmers. But is it true that this festival has had a positive impact on improving the welfare of flower farmers in Tomohon City? This study aims to examine the direct impact of the Tomohon International Flower Festival to the welfare of flower farmers. The data collection method used was a survey of 30 respondents in the village of Kakaskasen. The analytical method used is assessment by using a Likert scale and elaborated with statistical tool testing, namely: Kendal's tau, rank Spearman and coefficient of determination. Empirical findings showed the contribution of TIFF to The level of welfare is very small. The conclusion is that the welfare level of flower farmers has almost no relationship with the implementation of TIFF, because the level of welfare of farmers is basically influenced by the purchasing power or level of consumption of farmers.
\end{abstract}

Keywords - direct impact international flower festival, increase welfare, flower farmer

\section{INTRODUCTION}

At present the Indonesian government has placed tourism as a commodity, which is expected to be able to replace the oil and gas sector in terms of giving effect to the country's foreign exchange income [1]. This rationale is due to the rich ecological potential and socio-cultural resources that Indonesia has inherited. Many things have been taken by the Indonesian government, to make tourism a leading sector, one policy that is considered radical enough is to encourage all related sectors to support tourism development as a leading sector.
The policy penetrated almost all regions in Indonesia, which is placing the top seed in terms of tourism revenue for the region. Opening of various infrastructure accessibility of transportation lines as well as various other facilities improvements, enabling a variety of potential ecological and social.

Culture to serve as the object and attractions. One of the event's attractions the area is so heavily promoted is themed festivals social-cultural characteristic of the local community. Starting from the festival of agricultural / plantation results, culture and even natural ecology.

In North Sulawesi Province there are several festivals that are often held such as in the city of Manado, there is a sail Bunaken festival and FIESTA Festival, in Bitung city there is the Lembeh Strait festival. Whereas in Tomohon City there is the Tomohon International Flower Festival which is commonly abbreviated as TIFF. TIFF has become the annual agenda of the Tomohon City government. TIFF was made to promote Tomohon City as the City of Flowers, where the life of the community has a characteristic as a flower farmer, in addition to the promotion of various tourist attractions in the city of Tomohon.

It should also be noted that the TIFF festival has been attended by many regions in Indonesia as well as several representatives of countries from outside, and because it has been implemented almost seven times, it has significantly affected the people of Tomohon, especially for flower farmers. But whether this has been proven to provide a positive impact on income and improve the welfare of flower farmers in Tomohon City. The purpose of this research is to examine the direct impact of TIFF on the level of welfare of flower farmers in Kakaskasen Village, Tomohon City.

\section{LITERATURE REVIEW}

\section{A. Tourism}

Tourism is a temporary transfer of people to an area outside their place of residence and workplace, the activities carried out guarantee them during their stay in the destination and facilities that are made to meet their needs [2]. Tourism is a 
temporary journey from one place to another which is carried out by individuals or in groups as an effort to find balance and happiness in the environment in the social, cultural, natural and scientific dimensions [3]. Tourism is a combination of symptoms and relationships that arise from the interaction of tourists, business, government, host and community in an interesting process and serve tourists and other visitors [4]. Tourism consists of only three words that are repeated, namely "image, image and image" means that all tourism activities concerning the image, including service, security all depends on the image, if the image is damaged then the tourism industry is destroyed [1].

\section{B. Tourist Attraction}

There are two types of objects and tourist attractions, namely [5]: (1) Objects and tourist attractions created by God Almighty that are tangible (2) tourism objects and attractions created by human beings in the form of museums, ancient relics, historical relics, cultural arts, agro tourism, water tourism, hunting tours, nature adventure tours, recreational parks and entertainment venues.

That a tourist destination has an attraction besides having to have tourist objects and attractions, must also have three attractive conditions [6], namely (1) something that can be seen (something to see); (2) something can be done (something to do); (3) and something that can be purchased (something to buy). Whereas according to Spillane, there are five important elements in a tourist attraction [7], among others: (1) attraction, concerning matters that attract tourists, (2) facilities or facilities needed; (3) infrastructure of objects; (4) transportation, or mode of transportation; (5) hospitality or hospitality, attitude in serving and receiving guests. Furthermore Mudana states that there are three types of resources in tourism [1], including: (1) natural resources or natural resources such as mountains, beaches, wild areas, deserts, oceans, lakes, flora and fauna, etc.; (2) man-made resources or man-made resources such as historical cities, villages, entertainment, recreational and sports mixes, monuments, sites, building relics, museums and so on; (3) human resources or human resources such as the population of a destination, social cultural relations of the population, cultural values, artistic and cultural activities.

From several classifications of various categories of elements and types of objects and tourist attractions, a tournament of flower festival will be held by the Tomohon City government, entering as a tourist

\section{METHODS}

Data collection method is a survey of 30 respondents, with the intention only for information purposes, assuming the character of the respondent must be the same. Respondents in this study must meet one of the following criteria: (1) Permanent farmers who live in the Kakasksen Village, (2). Flower Farmers, or also have flower plants in addition to having other types of plantation / agricultural crops and (3) Farmers who understand / know about conducting a flower festival in Tomohon City while the analytical method used is rank spearman, kedal's tau and coefficient of determination.

\section{RESULTS AND DISCUSSION}

Kakaskasen village, North Tomohon Subdistrict Tomohon City is located at an altitude of $40-90 \mathrm{~m}$ above sea level, with a flat topography of the land surface to wavy, hilly and mountainous. This total area is $\pm 1,428$ ha with air temperature 190C - 290C which has a cool climate. The boundaries of the Overall are: north of Kinilow Village, south of Mount Mahawu, east of Talete Dua Village and west of Mount Lokon.

The population in Kakaskasen Village is $\pm 19,235$ people, where the number of men is $\pm 8,675$ people and percent and women are \pm 9560 people. The livelihoods of the people in this whole are farmers, construction workers, traders, civil servants, retirees working in the services sector. Especially for the education strata of the community in the Kakaskasen village on average the level of education of the community has received a decent education that is up to high education.

The condition of farmers and ornamental flower traders according to Rapar et al., explains that: The types and interest cultivated by traders through 2 (two) ways [8], namely First, from the decorative flower cultivation activities and second, from the results of the purchase of ornamental flowers so the farmers other decorative flowers. Every trader attempts between 10 - 22 types and eight of them are the most frequently cultivated, because the demand for this type of flower is the most. In one hectare of land, the type and amount of ornamental flower production produced by each farmer varies. Further explained that the 5 (five) types of ornamental flowers that are most commonly cultivated are Anthurium, Aster, Crysant, Kerk Kelly and Radiolan, while the most frequently cultivated by ornamental flower traders are the five types plus the Yellow Trim, Tulip and local Gladiolus types.

The purpose of this study is to prove whether the International Flower Festival (TIFF) Tournament event has a direct impact on the welfare level of flower farmers in Tomohon city. Characteristics of respondents who became the sample of the study were the first number of respondents 30 respondents with the following results of gender, namely 53.33 percent of men while women, 46.67 percent. For ages: predominantly ages $41-50,40$ percent; $31-40,36.67$ percent; > $51,13.33$ percent and 20-30.10 percent. While the education level is dominated by high school, 40 percent; First-level secondary school, 30 percent; Primary school, 13.33 percent and Bachelor, 16.67. In conclusion, the distribution of characteristics of respondents fulfilled the requirements in data collection.

Correlation test results of TIFF Event implementation with the Flower Farmer Welfare Level are shown in table 1. In the table the researchers used non-parametric statistical tests using the correlation test of Kendal's Tau and Spearman. The use of non-parametric statistical tests was carried out because: (a) the data or samples analyzed came from the population with data distribution patterns that were not normally distributed or unknown normality, (b) the variables studied could only be measured on a nominal measurement scale. In the sense that the variables are grouped into a particular category and then the frequency is calculated and (c) the research variable is data in the measurement scale, i.e. the variables are arranged in 
sequence based on the level then stated in the first, second, third and so on [9].

Based on the test, the correlation between Kendal's Tau is 0.11 and Spearman 0.12. On the figure based on the interpretation table, the relationship is categorized as having a relationship but very weak, which is in the range of $0.10-0.19$. Then the significant value is if $\mathrm{p}<0.05$ means there is a significant relationship and $\mathrm{p}$ value $=0.439<0.05$ (Kendal's Tau) and $p=0.525<0.05$ (rank spearman), which means that the two variables even though tested with two different correlation tools have a relationship but are very weak and do not have a significant relationship.

Then for the coefficient of determination that is $r 2$ and $r$ value taken from one of the Spearman rho correlation test results is 0.12 so $\mathrm{r} 2=0.122$ the result is $0.0144 * 100=1.44$, meaning that the variable event TIFF is the determining variable of the variable welfare level of the flower farmers is very small contribution is only 1.44 The remaining $98.56 \%$ is influenced by other variables that are not thorough in this study.

TABLE I. CORRELATIONS

\begin{tabular}{|c|c|c|c|c|}
\hline \multicolumn{5}{|c|}{ Correlations } \\
\hline & & & $\begin{array}{c}\text { TIFF } \\
\text { EVENT } \\
\end{array}$ & $\begin{array}{c}\text { PROSPERITY } \\
\text { LEVEL }\end{array}$ \\
\hline \multirow[t]{6}{*}{$\begin{array}{l}\text { Kendall's } \\
\text { tau_b }\end{array}$} & \multirow[t]{3}{*}{$\begin{array}{l}\text { TIFF } \\
\text { EVENT }\end{array}$} & $\begin{array}{l}\text { Correlation } \\
\text { Coefficient }\end{array}$ & 1.000 & .111 \\
\hline & & Sig. (2-tailed) & . & .439 \\
\hline & & $\mathrm{N}$ & 30 & 30 \\
\hline & \multirow{3}{*}{$\begin{array}{l}\text { PROSPE } \\
\text { RITY } \\
\text { LEVEL }\end{array}$} & $\begin{array}{l}\text { Correlation } \\
\text { Coefficient }\end{array}$ & .111 & 1.000 \\
\hline & & Sig. (2-tailed) & .439 & . \\
\hline & & $\mathrm{N}$ & 30 & 30 \\
\hline \multirow[t]{6}{*}{$\begin{array}{l}\text { Spearma } \\
\text { n's rho }\end{array}$} & \multirow[t]{3}{*}{$\begin{array}{l}\text { TIFF } \\
\text { EVENT }\end{array}$} & $\begin{array}{l}\text { Correlation } \\
\text { Coefficient }\end{array}$ & 1.000 & .121 \\
\hline & & Sig. (2-tailed) & . & .525 \\
\hline & & $\mathrm{N}$ & 30 & 30 \\
\hline & \multirow{3}{*}{$\begin{array}{l}\text { PROSPE } \\
\text { RITY } \\
\text { LEVEL }\end{array}$} & $\begin{array}{l}\text { Correlation } \\
\text { Coefficient }\end{array}$ & .121 & 1.000 \\
\hline & & Sig. (2-tailed) & .525 & . \\
\hline & & $\mathrm{N}$ & 30 & 30 \\
\hline
\end{tabular}

From the results of a very low correlation test and not having a significant relationship value, the researchers found that the level of welfare of flower farmers was not influenced by the implementation of the TIFF event or the celebration did not have a direct impact on the welfare of flower farmers. Held or not held will not affect the value of the welfare of farmers.

The direct impact of celebrations or festivals could only be felt by accommodation and restaurant owners [10,11]. The two biggest festivals in Sweden have increased the reception of accommodation for hotels in Stockholm and Gothenburg. Assessing there is a positive correlation between festivals and spending spent by tourists, they are testing at the largest annual festival in Scotland in the North Carolina region [12].

Local festivals are increasingly being used as instruments to promote tourism and improve regional economies [13]. This is often reflected in the level of public assistance available to them. However, it is difficult to assess the level of the festival's contribution to local economic growth. It is closely related to research conducted at the flower festival celebration with the level of welfare of flower farmers in Kakaskasen village. That the level of welfare cannot be influenced or does not have a direct relationship with any festival celebrations, because festival celebrations are only temporary, and even if they relate directly only to the level of hotel and restaurant lodging.

The things that influence or have a direct relationship with the level of welfare of farmers are among others data on consumption and expenditure of agricultural households. This means that the higher the level of consumption spending and expenditure, the more the welfare of farmers increases, or shortened the purchasing power of farmers $[14,15]$.

So based on the results of these studies prove that the level of welfare of flower farmers in Tomohon City is influenced and there is no connection with the implementation of the International Flower Festival Tournament which is routinely scheduled in the City each year

\section{CONCLUSION}

Based on the purpose of the study, to assess the impact of the TIFF (Tournament International Flower Festival) event on the Flower Farmer Welfare Level in the Village / Kakaskase Village, using the Spearman rank correlation test and Kendal's Tau shows very low relationships, namely $\mathrm{r}=0.12$ and 0.12 , meaning that the implementation of TIFF is almost there is no direct relationship with the level of welfare of flower farmers. Then the significant value is if $\mathrm{p}<0.05$ means there is a significant relationship, and $\mathrm{p}$ value $=0.439<0.05$ (Kendal's Tau) and $p=0.525<0.05$. This means that the two variables even though tested with two different correlation tools there are relationships but are very weak and do not have a significant relationship. The result of the determination test also produces r2 $=0.122$ (Spearman Rho test results) the result is $0.0144 *$ $100=1.44$, meaning that the variable TIFF event as a determining variable for the variable welfare level of the flower farmers is very small its contribution is only $1.44 \%$ the remaining $98.56 \%$ is influenced by other variables that are not accurate in this research.

Thus this proves that the welfare of bungan farmers is not affected by the presence or absence of the TIFF event. Festival implementation only has a direct impact on lodging and restaurant income, while the level of welfare of farmers only relates to the purchasing power of the community (farmers) or the level of consumption of farmers.

\section{REFERENCES}

[1] I.G. Pitana and P.G. Gayatri, Sosiologi Pariwisata. Yogyakarta. Bali: PT the Network, 2005.

[2] A. Matieson and G. Wall, Tourism: Economic, Phisical and Social Impact, New York: Longman John, Willy and Sons, 1982.

[3] J.J. Spillane, Ekonomi Pariwsata. Sejarah dan Prospeknya. Jakarta: Kanisius, 1987.

[4] N.S. Pendit, Ilmu Pariwisata, Sebuah Pengantar Perdana. Jakarta: PT Pradnya Paramita, 2002 
[5] Undang-Undang Republik Indonesia Nomor 9 tahun 1990 tentang Kepariwisataan Tentang Kepariwisataan.

[6] A.H. Karyono, Kepariwisataan. Jakarta: Grasindo, 1991.

[7] J.J. Spillane, Pariwisata Indonesia. Siasat Ekonomi dan Rekayasa Kebudayaan. Jakarta: Kanisius, 1994.

[8] L.N. Rapar, C. Talumingan, E.O. Laoh and E. Ruauw, Analisis Pendapatan Pedagang Bunga Hias di Kelurahan Kakaskasen Kota Tomohon. In COCOS, vol. 5, no. 1, 2014.

[9] Lukiastuti and Hamdani, Statistika Non Parametrik; Aplikasinya dalam Bidang Ekonomi dan Bisnis. Jakarta: PT. Buku Seru, 2012.

[10] K. Brännäs and J. Nordström, "Tourist accommodation effects of festivals," Tourism Economics, vol. 12(2), pp. 291-302, 2006.
[11] D. E. E. P. A. K. Chhabra, E. Sills and P. Rea, "Tourist expenditures at heritage festivals," Event Management, vol. 7(4), pp. 221-230, 2002.

[12] D. Chhabra, E. Sills and F.W. Cubbage, "The significance of festivals to rural economies: Estimating the economic impacts of Scottish Highland Games in North Carolina," Journal of travel research, vol. 41(4), pp. 421-427, 2003.

[13] D. Felsenstein and A. Fleischer, "Local festivals and tourism promotion: The role of public assistance and visitor expenditure," Journal of Travel Research, vol. 41(4), pp. 385-392, 2003.

[14] M. Rachmat, "Nilai tukar petani: Konsep, pengukuran dan relevansinya sebagai indikator kesejahteraan petani," Forum Penelitian Agro Ekonomi, vol. 31, No. 2, pp. 111-122, 2013.

[15] Analisis Kesejahteraan Petani 2017 [Online] Retrieved from: http://pusdatin.setjen.pertanian.go.id/ atau http://www.pertanian.go.id 